\title{
YAROSLAVL' REVISITED:
}

\section{Assessing Continuity and Change in Russian Political} Culture Since 1990

\author{
Jeffrey Hahn \\ Villanova University
}

\section{NGEERT}

The National Council for Eurasian and East European Research

$91017^{\text {th }}$ Street, N.W.

Suite 300

Washington, D.C. 20006

TITLE VIII PROGRAM 


\section{$\underline{\text { Project Information }}^{*}$}

Contractor:

Principal Investigator:

Council Contract Number:

Date:
Villanova University

Jeffrey Hahn

820-06

February 14, 2005

\section{Copyright Information}

Individual researchers retain the copyright on their work products derived from research funded through a contract or grant from the National Council for Eurasian and East European Research (NCEEER). However, the NCEEER and the United States Government have the right to duplicate and disseminate, in written and electronic form, reports submitted to NCEEER to fulfill Contract or Grant Agreements either (a) for NCEEER's own internal use, or (b) for use by the United States Government, and as follows: (1) for further dissemination to domestic, international, and foreign governments, entities and/or individuals to serve official United States Government purposes or (2) for dissemination in accordance with the Freedom of Information Act or other law or policy of the United States Government granting the public access to documents held by the United States Government. Neither NCEEER nor the United States Government nor any recipient of this Report may use it for commercial sale.

\footnotetext{
* The work leading to this report was supported in part by contract or grant funds provided by the National Council for Eurasian and East European Research, funds which were made available by the U.S. Department of State under Title VIII (The Soviet-East European Research and Training Act of 1983, as amended). The analysis and interpretations contained herein are those of the author.
} 


\section{Executive Summary ${ }^{1}$}

The purpose of this paper is to address the following questions. How has support among Russians for democratic values and institutions changed since 1990? Does such support depend on short-term calculations of economic and governmental performance or does it exist independently of such calculations? And finally, what are the implications of answers to these questions for the prospects for democracy in Russia?

The significance of the first question has become especially relevant since the transfer of presidential power from Boris Yeltsin to Vladimir Putin on 1 January 2000. From the beginning of the democratic experiment in Russia in 1990, Russians were led by Boris Yeltsin, the first popularly elected Russian president. Despite Yeltsin's public commitment to the building of democratic institutions, the system he left to his successor was at best a "delegative" democracy in which an elected chief executive exercised power largely without institutional constraints (O’Donnell, 1994). Most assessments of Yeltsin's impact on democratization and support for democratic values among Russians are quite negative (Huskey, 2001; Shevtsova, 1999). As Archie Brown (Brown, 2003, p.24) writes of this period: "one is forced to conclude that the experience of the 1990s did little to reinforce that strand in Russian political culture supportive of democratic principles." 


\section{Introduction}

The purpose of this paper is to address the following questions. How has support among Russians for democratic values and institutions changed since 1990? Does such support depend on short-term calculations of economic and governmental performance or does it exist independently of such calculations? And finally, what are the implications of answers to these questions for the prospects for democracy in Russia?

The significance of the first question has become especially relevant since the transfer of presidential power from Boris Yeltsin to Vladimir Putin on 1 January 2000. From the beginning of the democratic experiment in Russia in 1990, Russians were led by Boris Yeltsin, the first popularly elected Russian president. Despite Yeltsin's public commitment to the building of democratic institutions, the system he left to his successor was at best a "delegative" democracy in which an elected chief executive exercised power largely without institutional constraints (O'Donnell, 1994). ${ }^{2}$ Most assessments of Yeltin's impact on democratization and support for democratic values among Russians are quite negative (Huskey, 2001; Shevtsova, 1999). As Archie Brown (Brown, 2003, p.24) writes of this period: "one is forced to conclude that the experience of the 1990s did little to reinforce that strand in Russian political culture supportive of democratic principles."

Since 2000, Russia has been led by Yeltsin's chosen successor, Vladimir Putin, also popularly elected. Assessments of his successor's commitment to democracy, however, have been even gloomier. One observer (Herspring, 2005, p.295) concludes flatly, "Putin is clearly more authoritarian than Yeltsin was." Another (Daniels, 2000) calls it a "democratic dictatorship." Harley Balzer has coined the term "managed pluralism" to describe the Putin administration, but he makes it clear (p.220) that this does not correspond to democracy. These 
views are widely shared by others, some of whom suggest that the return to authoritarian rule is a natural fit with traditional Russian political culture. ${ }^{3}$ The conclusion of Putin's first term in office and his re-election to a second term in March 2004 would seem, therefore, to be an opportune time to revisit the question of how public support for democratic values has changed since the democratic experiment in Russia began.

Beyond the important substantive question of whether there is public support for democracy among Russians, a comparison of the political attitudes, values and beliefs held by Russians today with those held in the 1990s provides a sort of natural laboratory for testing theories of political culture. In particular, it may enable us to compare alternate paradigms for understanding post-Communist politics, notably those offered by institutional and rational choice perspectives. These perspectives would suggest that popular support for democracy is a function of how well institutions of government perform economically and politically.

Put another way, people will prefer a democratic system to a more authoritarian one if they perceive that they are better off than they were. Because such calculations are essentially instrumental, popular support for democracy can change fairly quickly in response to relatively short term policy changes. In this view, any long standing normative commitments Russians may, or may not, have about democracy (the "culturalist" explanation) are essentially irrelevant to democratization in Russia because they are not particularly useful in explaining support for democracy.

This paper offers tentative answers to these questions, both substantive and theoretical, on the basis of longitudinal research carried out by the author in Yaroslavl', Russia from 1990 through 2004. Much of the research was qualitative involving an average of one trip a year for observation and personal interviews. But, it was also quantitative. A fully representative opinion 
survey conducted in 1990 was replicated in 1993, 1996 and most recently, in 2004. While caution must be exercised about generalizing from a single case, the advantage of this study is that it was conducted with a relatively homogenous population, one not dissimilar to other ethnically Russian areas of Western Russia. Furthermore it is a unique data set in that is enables us to compare political attitudes and beliefs held by Russians at the very beginning of the democratic experiment with those held today.

\section{Literature Review}

The prevailing view of Russian political culture before Western social scientists were able to conduct independent survey research in Russia starting in 1989 was that it bore the hallmarks of Russia's authoritarian past. Much of what we thought we knew was based on an analysis of Russian history. The authoritarian traditions of pre-revolutionary Russia had not been changed by Soviet rule, the argument went; rather they were reinforced, suggesting that a continuity of political thinking by Russians made them predisposed to accept authoritarian political institutions. (A discussion of this historical understanding is made by Alexander Lukin.) ${ }^{4}$

Two pioneers in the study of political culture in Communist societies shared this view in varying degrees. Stephen White was the first to write a book (White, 1979) exclusively on the question of political culture in the Soviet Union. White made it clear that in his view, Bolshevik leadership did not mark a radical departure from the autocratic political culture prevailing in preRevolutionary Russia. On the contrary, the political culture of the Soviet Union represented continuity with that inheritance. In a later publication (White, 1984), he even more strongly articulated this point of view and suggested that political scientists should "take the historical 
cure" and acknowledge a "degree of causal weight" to political culture in understanding the distinctiveness of Soviet politics. If this "cultural continuity" thesis proved accurate, prospects for successful democratization in Russia would appear slight. Such a political culture would likely prove to be incompatible with democratic institutions.

The other pioneer in the study of political culture in Communist countries is Archie Brown. The ground breaking book on political culture and change in Communist states which he edited with Jack Gray was published in 1977, but in fact had been in preparation since the 1970's. Brown's views on the impact of Russian history on Russian political culture appear to be more open to the possibility of change than those of White. Writing in 1987 about what Gorbachev might mean for Russia (Brown, 1989), he also noted (p.19) the weight of history on Russian political culture. "Because political cultures are historically conditioned, the long-term authoritarian character of the Russian and Soviet state constitutes a serious impediment to political change of a pluralizing, libertarian, or genuinely democratising nature." Yet, impeding change is not the same thing as preventing it and Brown goes on later in the same piece to suggest that a continuation of Gorbachev's liberalizing policies might be the catalyst. On p.30 he writes that 'it is unlikely that such an unusually prolonged period of reform in Russian and Soviet history could fail to have a significant impact on the political culture'.

However, since 1989, when Gorbachev's policy known as perestroika first made it possible, Western social scientists have been able to use research methods commonly used to study political culture elsewhere, most notably survey research. The results of these initial studies were somewhat unexpected in that they indicated the existence of a good deal more support for democratic values and institutions than would have been predicted by the continuity thesis. My own findings (Hahn, 1991) based on research in Yaroslavl' in 1990 suggested that 
attitudes, values, and beliefs about democracy among Russians were not altogether different from what was found in other industrialised democracies, including the USA. Generally speaking, these findings were independently confirmed in a number of other studies (Gibson, et al., 1992; Reisinger et al., 1994; Gibson, 1996) based on survey research conducted in the early 1990s.

The results of these early studies came under increasingly critical scrutiny both substantively and methodologically in the mid and late 1990s. Substantively, new research became available which showed that the early optimism about Russian support for democracy may have been premature, an artifact of early enthusiasm for reform. As Archie Brown has pointed out (Brown, 2003, p. 21), 1990-91 were years of excitement and high expectations among Russians, but "a decade later there was much more disillusionment". My own research, replicated in Yaroslavl' in 1993 and 1996, led me to conclude (Hahn, 2001, p.106) that: "By almost all the measures of diffuse support, including political efficacy, political trust, electoral commitment, and political interest, there has been an overall drop." Especially after 1993, many Russians seemed to become increasingly disillusioned about what democracy in Russia meant. As the literature cited in this report suggests, most observers feel that Russia has become less democratic over the last decade and a half. It would hardly be surprising then to find a growing gap among Russians between a normative attachment to democratic values and an assessment of the current regime as being undemocratic.

Methodologically, a growing number of specialists argued that traditional Western survey research failed to capture what Russians really think about politics. In his book on political culture in post Soviet Russia, James Alexander writes (Alexander, 2000, p.56) that: "There is 
considerable doubt whether surveys are the best means for carrying out this research" citing problems of attitudinal volatility, as well as the problems of writing good questions and of interpreting meaning (see also, Wyman, p.131; Whitefield and Evans, 1994).

Alexander Lukin offers a quite different critique in his analysis of the political culture of those who led the democratic movement in Soviet Russia during perestroika. Noting that Western survey research became more cautious about Russia's democratic prospects after 1993, Lukin argues that the real problem with this type of research, and indeed all Western research on democratization in Russia, is that it's Eurocentric. He uses the term (p.33) "occidocentric" to describe the Anglo-American theoretical bias he says is built into Western research and which he believes prevents Western survey research from understanding Russian political culture.

This brings us to more current research. Timothy J. Colton and Michael McFaul claim (p.91-92) that there is an emerging "narrative" about Russian political attitudes to the effect that Russians are "giving up on democracy." According to the authors, this narrative revisits arguments cited earlier about cultural continuity by "anchoring present day anti-democratic sentiment in an unbroken continuum of Russian values and traditions." They also acknowledge the argument being made that Putin's emphasis on the need for order resonates with Russians because it is congruent with an essentially authoritarian political culture. In short, democratic consolidation has failed to take hold in Russia because Russia lacks democrats. It should be emphasised that Colton and McFaul go on to reject this view arguing that while many Russians reject their current system as undemocratic, they do not reject democratic values. On the contrary, their data show considerable support for them. Based on an analysis of survey data gathered between November 1999 and May 2000, they find (p.117) that "the people have assimilated democratic values faster than the elite have negotiated democratic institutions". 
A similar conclusion is reached by James L. Gibson, one of the first to conduct survey research in post-Soviet Russia showing that there was broad support for democratic values and institutions. In an analysis based on three panel surveys conducted between 1996 and 2000, he investigated the effect of poor economic performance on Russian support for democracy and addressed the question of whether it had declined as a result. His findings (Gibson, 2001) indicate that Russians' perceptions of economic performance have had little impact on support for political democracy although they have had more of an effect on support for market reforms. He also found that attitudes were little changed from the late 1990's. Gibson concludes (p.123) that: "The overwhelming conclusion of this research is that the nascent democratic culture in Russia has not eroded over the course of the last part of the 1990s. Russian culture may not be very supportive of a market economy, but the evidence is that few prefer an alternative to democratic governance."

Stephen White offers quite a different assessment. Continuing his earlier interest political culture in Soviet Russia, White has closely watched the evolution of Russian public opinion since the collapse of the Soviet Union. In an article published in 2002 and based, in part, on opinion surveys he and his colleagues conducted in 2001, he asks: "Ten Years On, What do Russians Think?" His answer is not encouraging at least for creating a "liberal democracy" in Russia rather than merely an "electoral democracy."

White found that many Russians prefer Communist rule to what they have now. When asked which political system was most appropriate for Russia, nearly a third expressed support for the Soviet regime as it existed until 1985. While there was some expression of general support among respondents for democratic values and institutions, the data reveal low levels of confidence and high levels of mistrust in the system as it exists in Russia today. White concludes 
(p.49) by suggesting that the continuity hypothesis may not have entirely outlived its usefulness in Russia because today's political system is “more likely to emphasise the Soviet and prerevolutionary tradition of executive authority than the Western tradition of limited and accountable government based on the consent of a mass electorate."

As noted previously, one of the principal theoretical challenges to political culture comes from the perspective of rational choice theory. There have been a number of recent attempts to use research conducted in post Communist societies to compare the explanatory value of the two approaches using survey research. In one case, Whitefield and Evans (1999) examined public opinion about the democratic transitions that have taken place in two former Communist countries - the Czech and Slovak republics. The authors sought to determine whether differences in levels of commitment to democracy among their respondents were better explained by long standing normative orientations acquired in the process of political socialization (a culturist explanation) or by short term calculations of economic and political performance (a rational choice explanation). The authors found (p.149) that higher levels of support for democracy in the Czech Republic were best explained by short-term economic performance "without recourse to notions of long-standing political culture".

However, Whitefield (2005) offers a more ambiguous assessment about Russia. He suggests that at least one important element of post Communist Russian political thinking - an individual's choice of state identity - may be better explained by long standing normative beliefs, at least in conditions of uncertainty. He concludes that political culture and instrumental approaches may be jointly necessary for understanding public attitudes and that "there is considerable ongoing value in a political culture approach to citizens' political attitudes even in post-Communist conditions". A similarly ambiguous assessment regarding the two approaches is 
found in an analysis of political efficacy in Russia. Tamara Karaman (2004) concludes that while external efficacy is better explained by economic satisfaction, internal efficacy is more a function of political awareness, a cultural variable. The research presented in this chapter proposes a similar test of the explanatory value of these two theoretical approaches.

\section{Concepts/Hypotheses}

Since the introduction of the term into the political science literature in the nineteen fifties, few concepts have engendered more controversy and criticism than political culture. This is not the place to review the history of the concept, which in any case has been done by others, notably Archie Brown (Brown, 1996; Brown, 2003). Given the controversy, however, it is incumbent on the author of a chapter dealing with political culture to make clear where he stands on at least some of the issues. At a minimum, we need to answer the following questions. What do we mean by the term? Does our definition include behavior? How do we distinguish between opinion and political culture? Why do we think the concept matters? And, finally, what measurements are appropriate for its study? Because the author has addressed these questions at some length elsewhere (Hahn, 2001, p.76-79), what follows is a summary of his positions. The issues of measurement are discussed in the section on research design below.

Following Almond (1990), Brown and Gray (1977), and most of those who have used the concept, this research adopts a definition that understands political culture as the subjective values, attitudes and beliefs which members of society hold about political life. ${ }^{5}$ While these orientations at the individual level may be cognitive (what one thinks they know about political life), normative (preferences about how things should be) and evaluative (what they think of how things are), political culture ultimately refers to values shared collectively by national, or sub- 
national, groupings. ${ }^{6}$ Political culture is distinguished from public opinion because it refers to deeper, sometimes even subconscious; values that are enduring and that are learned by an intergenerational transfer known as the process of political socialization. As a result, while political cultures can and do change, they do so only slowly over time.

The significance of political culture is independent of its ability to explain political behavior, although the two may be related. This author agrees with Brown (1984) in excluding behavior from the definition of political culture. However, as he notes (p.150), "To define political culture in such a way as to exclude behavior in no way implies a lack of interest in behavior". Nor does excluding behavior from the definition of political culture preclude finding correlations between them. In a similar vein, one must be cautious about assuming that political outcomes are directly linked to, or explained by, political culture. One of the problems with the 'continuity thesis' referred to earlier is that it conveys a certain determinism with respect to political change in Russia, (e.g., Russian political culture is so historically freighted with authoritarianism that democratic outcomes are precluded). Instead, this author shares the view that institutional outcomes and political culture are mutually dependent and that the causal arrow can go either way. While political culture may condition political outcomes and institutions, it is equally clear that political institutions can and do shape political cultures.

The preceding review of the literature suggests several tentative answers to the questions asked at the beginning of this chapter. One is that if Russia under Putin is indeed backsliding into an authoritarian regime is more congruent with that said to be characteristic of Russian political culture, then we would expect to find that whatever support there was for democratic values and institutions as measured by the variables of diffuse support (efficacy, trust, civic duty, interest, and support for a multi-party system) to have declined. 
Specifically, for the study at hand, given the erosion of support found between 1990 and 1996 (Hahn, 2001, p.106) we would expect to find further erosion of such values since 1996. Similarly, we would expect to find an increase in support for variables related to a strong state system and authoritarian leadership. Alternatively, however, if we find little change in these measures, especially those that measure values and not merely attitudes, ${ }^{7}$ then we may tentatively conclude that there at some level is a normative commitment to democracy even though Russians don't believe they live in one. Strong support for Putin would not be inconsistent with such a conclusion, but it may imply that such support is conditional.

The second question asked at the outset sought to explain any variance in the values and attitudes measured here as a function of short-term calculations of economic benefits. Following from the rational choice (or instrumental) perspectives reviewed previously, we would expect to find any changes in support for democratic values and institutions can be explained by short-term situational factors related to evaluations of economic and political performance. Specifically for our study, we would expect that assessments of economic well being, both socio-tropic (societal) and egocentric (personal), would explain most of the variation in political attitudes, as well their assessment of political reforms. Put another way, for respondents whose perceptions of economic and political performance since 1996 have been negative, attachment to democratic values and institutions will have declined more than for those whose situation improved since 1996.

\section{Research Design}

To explore these issues further, survey data from a longitudinal study of public opinion on politics undertaken in 1990, 1993 and 1996 in a single Russian city, Yaroslavl', was again replicated in 2004. Yaroslavl' is an industrial city of about 650,000 people located nearly 200 
miles northeast of Moscow in what is known as the 'Golden Ring' of ancient cities surrounding Moscow. Critics of the earlier research (Brown 2003, p.20; Wyman, 1997, p.131) raised questions about how representative the population is for other areas of Russia and the degree to which one can make generalizations from a single case. ${ }^{8}$ In fact, there is no way to know how generalizable our findings are without replicate studies elsewhere. The conclusions offered can only be asserted with any confidence for the population that was sampled.

At the same time, however, Yaroslavl' is overwhelmingly an ethnically Russian city (over 95 percent) and there is no a priori reason to believe that the responses of those interviewed are so far out of the mainstream of Russian public opinion as to constitute a unique case. On the contrary, by such measures as size, education, age, percent of the population engaged in industry and other indicators commonly used in determining comparability, Yaroslavl' appears to be similar to other regions of European Russia. Certainly, it is more typical than Moscow or St. Petersburg where the populations are more heterogeneous than in most Russian cities. In any event, the research findings presented in this work do not claim to offer universally generalisable conclusions about Russian attitudes toward democracy, but rather seek to generate usable propositions about attitudinal change in Russia, especially after one term of Putin's presidency, which may be refuted or confirmed by other research.

The research presented in this chapter compares data collected in August-September 2004 with data from the opinion surveys conducted in 1990, 1993 and 1996. Those surveys interviewed respondents drawn from voter lists using a skip interval random sample. Sample sizes in each case were about 1250 with the actual number of those interviewed being 975,1019 , and 962, respectively. In 2004, because comprehensive voter lists were no longer available, sampling was based on an initial quota sample using age and gender in proportion to the 
population. Electoral districts down to the precinct level were then chosen on a randomized basis and apartments were chosen randomly on a skip interval basis. Interviews were conducted only when respondents matched the assigned quotas for age and gender.

As a result of the change in sampling procedures, the response rate in 2004 was higher. Of 1217 surveys turned in, 85 had to be discarded, leaving a net total sample of 1132 . Interviews were conducted in person by experienced interviewers who were also trained in use of the specific questionnaire. In 2004, approximately 28 percent of the interviews were verified to make sure they had actually taken place. All four surveys were overseen by Tatiana Rumiantseva, a professional sociologist who is now Director of the Centre for the Study of Public Opinion and Sociological Research of Yaroslavl'. Rumiantseva is a native of Yaroslavl' as were the team of 39 trained and experienced interviewers she employed in 2004. In short, every effort was made to ensure that the survey results would be representative of the population within a margin of error of plus or minus 3 percent at a .95 level of confidence. ${ }^{9}$

The questionnaire used in the first survey was prepared in advance in the United States by the author with the assistance of Dr. Alexander Gasparishvili of Moscow State University's Centre for Sociological Research. Many of the questions included were drawn from standard measures of political culture used in the West. Dr. Gasparishvili is fluent in English and has taught in the United States, while the author is fluent in Russian. Back-translating the questions used in the Western survey research helped to ensure that the questions used would elicit meaningful responses while laying the basis for comparability. The second survey replicated most of the questions used in the first, but added some additional items designed to measure 
attitudes toward political and economic reforms. The third survey replicated the questions used in the second and added several more related to the measurement of economic performance. This third survey was used with minor modifications in August-September 2004.

In this research, we look primarily at sources of diffuse support (Easton, p. 273) for democracy. ${ }^{10}$ Data are also reported regarding how respondents view their leaders and how they feel about economic and political reforms currently underway. The dependent variables chosen for analysis are those commonly associated with diffuse support: political efficacy, political trust, support for elections, political interest and support for a multiparty system. ${ }^{11}$ In addition, however, we look at levels of political participation. For each variable with multiple measures, additive scales were created to form single dependent variables. These are used for bivariate and multivariate analysis.

Finally, there are a number of variables aimed at measuring orientations more specifically related to political and economic reforms. Some of these were also combined into additive scales. Independent variables used in this analysis include measures of how respondents evaluate the government's economic performance, both socio-tropically and egocentrically, and prospectively and retrospectively. Due to limits of space, the effects of socio-economic status variables (education, income, occupation), as well as standard demographic variables, including age, gender and place of birth cannot be included here, but will be examined in future analyses. An additive scale was created measuring respondents' overall evaluation of economic performance.

The first section of the data analysis presents a comparison of the frequency distributions for responses to the same questions at four points in time (1990, 1993, 1996 and 2004) for each of our dependent variables. These give some indication of whether there has been any erosion 
over time of diffuse support associated with democratic systems. The second section explores the question of whether variance in our dependent variables is a function of how well institutions of government have performed economically. To do this, in cases where more than one item of measurement was used, additive scales were constructed to provide summary measures of the dependent variables. They are then cross-tabulated with the independent variables. Specifically, we want to know if respondents who feel that the economic life has gotten worse, societally and personally, also less likely to support democratic values. We will compare the relationship between these variables for 1996 and 2004.

As noted earlier there have been a number of criticisms about using survey research to assess the depth of the Russian commitment to democracy (Welch, 1993; Alexander, 1997). One of these is the argument that survey research fails to get at the deeper meanings of culture that might be revealed by anthropological methods. Another criticism (Brown, 2003, p.20) is that survey research is more appropriate to studying attitudes in stable societies; the Russian transition has been too rapid and turbulent to allow for more than transitory conclusions. And there is the argument (Bahry, 1999) that close-ended questions with forced choices do not enable the researcher to get at the differences that may be embedded within different layers of the respondents; poorly framed questions may miss these nuances. Nevertheless, there does seem to be a grudging consensus that, as Stephen White puts it (White, 2002, p.36): "With all its limitations, it is survey research that can most readily answer questions of this kind.”

One technique which may help to get at the deeper meanings and ambiguities that underlie responses to a survey questionnaire is the use of focus groups. As Richard Kruger (Kruger, 1994, p.239) writes, "Focus groups provide a special type of information. They provide a richness of data at a reasonable cost. They tap into the real life interactions of people and allow 
the researcher to get in touch with participants' perceptions, attitudes, and opinion in away that other procedures do not." Although the earlier research, which the 2004 project replicated, did not use focus groups, the 2004 study did. Between 30 September and 11 November, three focus groups with ten participants each and one with eight were held. The three groups of ten were divided into age cohorts, a younger group between 20 and 30 years of age, a middle group between 30 and 50 and an older group of individuals over 50. A final group of eight included members from each age group. Sessions lasted about two hours and were videotaped and later transcribed. The sessions were conducted under the guidance of Tatiana Rumiantseva at the Centre for the Study of Public Opinion and Sociological Research by moderators who have experience in this type of research. The author of this chapter worked out a list of prompts in advance with Rumiantseva. The material obtained in this manner is analysed along with the survey data in order to elaborate on the possible meanings of the responses gathered through the questionnaires.

\section{Findings}

\section{A. Attitudinal Change over Time}

\section{EFFICACY.}

Political efficacy measures the degree to which people feel subjectively that they can exercise control over the decisions by government that affect their lives. The concept was originally developed by Angus Campbell and his colleagues (1954) whose now classic study of American voting behaviour sought to explain why people voted or abstained. Many of the questions used by the authors to measure political efficacy were used in this study in order to provide a basis for comparison. ${ }^{12}$ The argument that subjective competence was central to a 
'civic' or participant political culture was also made by Almond and Verba in The Civic Culture (1963). More recent analyses have emphasized the distinction between feelings of internal and external efficacy. The former indicates an individual's perception of his or her own ability to understand political life, while the later indicates whether they feel the government is actually responsive to their input (see discussion in Karaman, 2004). Questions one, two, four and five in Table 1 were used to measure external efficacy while questions three and six measure internal efficacy. Questions one to four in Table 1 measure efficacy regarding national government; questions five and six ask similar questions, but for local government. ${ }^{13}$ Disagree responses in each case indicate low efficacy.

Several observations can be offered based on the data reported in Table 1. First, overall our respondents do not feel that they have very much control over what government does, locally or nationally. In no case does an efficacious response gain more than 34 percent. There was clearly a decline in efficacy at the national level from 1990 to 1993 suggesting support for the view (Brown, 2003, p.21) that early surveys of opinion were excessively optimistic reflecting the enthusiasm of the time. But from 1993 on feelings regarding efficacy remain little changed or decline.

However, there is one noteworthy exception to this generalisation. Responses to measures of internal efficacy (questions three and six) show a steady increase from 1993. Moreover, the figures for internal efficacy are generally higher than for external efficacy (questions one, two, four and five) and. In both 1996 and 2004, they are higher by a difference of 15 to 21 percent. It appears that although government is not perceived as being very responsive to citizen input, at least in some cases it is not because people lack a sense of subjective competence. 
Table I: Comparative Political Efficacy Measures for Local and National Government in Yaroslavl, 1990, 1993, 1996, and 2004 and in the United States, 1994* (in percentages)

$\begin{array}{cccc}1990 & 1993 & 1996 & 2004 \\ (\mathrm{~N}=975) & (\mathrm{N}=1019) & (\mathrm{N}=962) & (\mathrm{N}=1132)\end{array}$

\section{NATIONAL GOVERNMENT}

People like me don't have much say about what government does.

$\begin{array}{lcccc}\text { Agree } & 84.8 & 89.0 & 87.9 & 90.3 \\ \text { Disagree } & 9.0 & 6.3 & 6.7 & 6.7 \\ \text { Don't know } & 6.3 & 4.7 & 5.5 & 3.0\end{array}$

I don't think public officials care much what people like me think.

$\begin{array}{lcccc}\text { Agree } & 55.9 & 72.3 & 84.9 & 84.6 \\ \text { Disagree } & 29.4 & 15.4 & 7.9 & 9.5 \\ \text { Don't know } & 14.7 & 12.1 & 6.8 & 5.9\end{array}$

Sometimes government seems so comnlicated that neonle like me can't reallv understand what is going on.

$\begin{array}{lcccc}\text { Agree } & 69.4 & 70.9 & 74.3 & 67.1 \\ \text { Disagree } & 23.2 & 8.0 & 18.0 & 25.6 \\ \text { Don't know } & 7.5 & 8.4 & 7.7 & 7.3\end{array}$

Generally speaking, those we elect lose touch with the people quickly.

$\begin{array}{lrrrr}\text { Agree } & 61.0 & 87.4 & 81.9 & 88.2 \\ \text { Disagree } & 16.3 & 3.5 & 7.9 & 4.9 \\ \text { Don't know } & 22.6 & 9.0 & 9.9 & 7.0\end{array}$

\section{LOCAL GOVERNMENT}

People like me don't have any say about what the local government does.

$\begin{array}{lcccr}\text { Agree } & 83.3 & 83.6 & 82.2 & 84.3 \\ \text { Disagree } & 10.4 & 8.5 & 10.2 & 11.3 \\ \text { Don't know } & 6.0 & 7.9 & 7.6 & 4.6\end{array}$

Sometimes local government seems so complicated that a person like me can't really understand what is going on.

$\begin{array}{lcccr}\text { Agree } & 59.7 & 62.9 & 58.3 & 57.8 \\ \text { Disagree } & 30.6 & 23.8 & 30.8 & 34.0 \\ \text { Don't know } & 9.7 & 13.2 & 10.9 & 8.2\end{array}$


Moreover, although the level of powerlessness is high both nationally and locally, the data suggest that local government may be perceived as a bit more responsive than the national one. As the data in Table 1 indicate, while levels of efficacy declined from 1990 to 2004 on the national level, they did not do so at the local level. Nevertheless, regarding local government, in 2004 when we asked whether the respondents thought they could do anything if the city council made a decision they felt was wrong, ${ }^{14} 65$ percent said there would be "nothing" they could do, almost identical with the figure of 66 percent from 1996. Only eight percent indicated that they had ever tried to influence local decisions, up slightly from six percent in 1996. It is interesting to note that although most of our respondents thought there was little they could do to have an effect on an unjust decision by their local government, when asked if they felt it is necessary for the voters to have more means of influence on the decisions of the city government than they have now, 68 percent thought there should be.

\section{POLITICAL TRUST}

Political trust is an evaluative orientation towards government based on how well government meets normative commitments. Low levels of political trust are associated with political cynicism (Campbell, 1979, pp.87-95). Although most scholars would agree that political trust is essential to the functioning of democracy, there is disagreement about whether it is a source of specific or diffuse support (Heatherington, 1998, p.792). Those who argue the former position maintain that a decline in political trust reflects public judgment of the incumbent government's performance and can be changed by an improvement in that performance. Others maintain that 
political trust is a source of diffuse support because it is related to the public perception of regime legitimacy. Again, for the sake of comparison, the measures of political trust used in Table 2 are similar to those that have been used to measure political trust in the United States.

The data reported here suggest several points of interest. Overall, levels of political trust among our respondents are higher than levels of political efficacy. Why people might trust a government they feel they cannot influence is a question we shall turn to later. There are some important differences that emerge when one looks at trust of national and local governments. At the national level, political trust declined steadily from 1990 through 1996, but rebounds by 2004. This can be most clearly seen by combining the first two responses for each question. Thus, for example, in 2004, 54 percent of the respondents thought government made the right decisions half the time or more, up from 36 percent in 1996 and closer to the 57 percent thinking that in 1990. At the local level, however, the change has been steadily higher. In 2004, a fairly robust 61 percent thought their city council made the right decisions half the time or more compared with only 29 percent who thought so in 1990.

There are some other data from the survey which shed light on the question of political trust among our respondents but which are not reported in Table 1. In some ways, these data appear contradictory. On the one hand, our respondents perceive widespread corruption among those in government. 55 percent thought that "all or almost officials (dolzhnostnykh lits) all" take bribes while 25 percent thought it was only about half of them; 58 percent thought "all or almost all officials" showed favoritism to friends and connections with another 22 percent saying this was true for half. Dispiritingly, the numbers for both of these questions rose over those for 1996. 
Table 2: Comparative Measures of Political Trust for Local and National Government in Yaroslavl, 1990, 1993, 1996 and 2004 (in percent)

$\begin{array}{cccc}1990 & 1993 & 1996 & 2004 \\ (\mathrm{~N}=975) & (\mathrm{N}=1019) & (\mathrm{N}=962) & (\mathrm{N}=1132)\end{array}$

\section{NATIONAL GOVERNMENT}

\begin{tabular}{lccrr}
\hline \hline How much of the time do you think government makes the right decisions? & & \\
Almost always & 18.3 & 38.6 & 31.9 & 46.6 \\
Half the time & 39.2 & 32.4 & 51.5 & 37.9 \\
Rarely or never & 26.3 & 22.7 & 12.9 & 8.1
\end{tabular}

Would vou sav that government. when it makes decisions. takes care for the well-being of all the people or only a few?

$\begin{array}{lcccc}\text { Benefits all } & 36.3 & 14.3 & 7.7 & 10.3 \\ \text { Sometimes all } & 26.2 & 23.7 & 24.5 & 26.6 \\ \text { Benefits few } & 29.6 & 53.2 & 62.4 & 60.6 \\ \text { Don't know } & 7.9 & 8.8 & 5.4 & 2.5\end{array}$

Do you feel that a majority of those running the government are capable or do you think only a few are?

$\begin{array}{llllr}\text { A majority } & 24.7 & 13.0 & 8.5 & 15.9 \\ \text { About half } & 24.9 & 22.9 & 22.8 & 31.9 \\ \text { A minority } & 37.0 & 46.2 & 56.2 & 43.3 \\ \text { Don't know } & 13.2 & 18.0 & 12.4 & 8.9\end{array}$

\section{LOCAL GOVERNMENT}

\begin{tabular}{|c|c|c|c|c|}
\hline Almost always & 6.3 & 12.2 & 11.5 & 13.3 \\
\hline Half the time & 23.1 & 38.4 & 41.7 & 48.2 \\
\hline Rarely or never & 36.3 & 19.5 & 30.6 & 25.3 \\
\hline Don't know & 34.3 & 29.9 & 16.3 & 13.2 \\
\hline
\end{tabular}

Would you say that your local government when it makes decisions takes care for the well-being of all people or only for a few?

Benefits all

15.2

17.0

13.7

13.3

Sometimes all

23.3

31.2

33.0

37.1

Benefits few

46.3

38.7

46.9

42.8

Don't know

15.3

13.2

6.4

6.8 
On the other hand, it seems clear that political trust in executives is higher than for those in the legislative branch. This is especially true for President Putin who is much more trusted than his predecessor. In 2004, 78 percent said they trusted their current president somewhat or completely, compared with 22 percent saying the same for Yeltsin in 1996. The data also suggest that the mayor of Yaroslavl' is more trusted than city council members. It may also be significant that while very few respondents could name their representative to their legislatures, or the heads of the legislatures, over 95 percent could name the mayor and the governor of Yaroslavl'.

\section{ELECTIONS AND VOTING}

Electoral competition is perhaps universally regarded as the most central requirement for a democracy. Starting with the parliamentary and local elections held in March 1990, Russian elections have been competitive, though not necessarily always free and fair (Brown, 2001, p.554-556). One measure of public attitudes towards electoral participation is their sense of citizen, or civic, duty. Students of American voting behavior early on concluded that this attitude was a result of childhood socialization and that it was strongly correlated with voter turnout. As one author (Campbell, p.239) puts it, "Without a sense of citizen duty, very few people bother to vote; no other attitude can make up for this lack". The present study uses the questions developed by Angus Campbell and his colleagues at the University of Michigan to look at levels of civic duty among our respondents. 
Table 3: Comparative Levels of Popular Support for Democratic Elections in Yaroslavl, 1990, 1993, 1996 and 2004 (in percentages)

$\begin{array}{ccll}1990 & 1993 & 1996 & 2004 \\ (\mathrm{~N}=975) & (\mathrm{N}=1019) & (\mathrm{N}=962) & (\mathrm{N}=1132)\end{array}$

\begin{tabular}{l}
\hline \hline A good many local elections aren't important enough to bother with. \\
Agree \\
Disagree
\end{tabular}

If a person doesn't care how an election comes out, then that person shouldn't vote.

$\begin{array}{lcccc}\text { Agree } & 44.2 & 51.2 & 36.4 & 32.8 \\ \text { Disagree } & 50.8 & 37.5 & 53.1 & 61.9 \\ \text { Don't know } & 5.0 & 10.8 & 10.5 & 5.3\end{array}$

So many other people vote in national elections that it doesn't matter whether I vote or not.

$\begin{array}{lcccc}\text { Agree } & 27.5 & 39.3 & 28.8 & 29.2 \\ \text { Disagree } & 68.3 & 53.7 & 62.2 & 66.4 \\ \text { Don't know } & 4.2 & 7.1 & 9.1 & 4.3\end{array}$

It isn't so important to vote when you know your party (candidate) doesn't have a chance to win.

$\begin{array}{lcccr}\text { Agree } & 28.2 & 37.2 & 36.3 & 33.7 \\ \text { Disagree } & 62.0 & 52.2 & 52.7 & 60.4 \\ \text { Don't know } & 9.8 & 10.6 & 11.1 & 5.9\end{array}$

Like other studies (Colton and McFaul, p.103; White, 2002, p.45), the data indicate widespread support for the idea that voting is important. Generally speaking, this is true for all four of our surveys. However, it is interesting to note that the sense of civic duty among our respondents was stronger in 2004 than in 1996 and is closer to the figures for 1990 which was, arguably, a year when the novelty of competitive elections might have been expected to produce unusually high enthusiasm. Why? One answer may be that popular trust in political institutions, or at least in some political personalities, also rose. We have already noted the greater trust in Putin and the mayor of Yaroslavl', but there are data to suggest that this approval also extends to 
'Unified Russia', the political party which the public associates with support for Putin, and to the State Duma itself, though nowhere near as strongly. ${ }^{15}$

What is the significance of support for electoral participation? Stephen White (2002, p. 45) has argued that while competitive elections are welcomed by Russians in principle, that support doesn't necessarily translate into a feeling that voting matters much. Our findings on political efficacy reported above indicate a similar discrepancy between a strong sense of civic duty and low levels of efficacy. Indeed, it may be that while Russians support democratic values and institutions in the abstract, they feel, as White argues, disempowered when it comes to the current system. Two caveats may be offered to such a conclusion. However disempowered they may feel, our respondents do vote; 77 percent voted in the 2003 Duma elections and a robust 73 percent reported voting in the presidential and municipal elections held in March 2004. Another point of interest is that levels of civic duty are considerably higher for local elections (question \#1, Table 3). Combined with the earlier finding of greater political efficacy at the local level, it may be that people feel voting matters more locally.

\section{OTHER IndiCATORs: Political AwARENESS; A Multi-PARTy System}

There are two other indicators related to popular support for democratic values and institutions for which the author has gathered replicate data over four surveys. These relate to political awareness and support for a multi-party system. Political awareness has long been identified as necessary for a functioning democracy. Almond and Verba (1963) argued that those living in participant or civic culture would characteristically be more aware of, and informed about, politics. 
More recently, Tatyana Karaman (2004) concluded that political awareness was closely related to measures of internal efficacy among Russians. Like Almond and Verba, she maintained that political interest and political cognition are two components of political awareness. Using the standard question generally employed to determine political interest, ${ }^{16}$ those reporting interest "most" or "some of the time" declined from a high of 82 percent in 1990 to 68 percent in 1993 and less dramatically from 64 percent in 1996 to 61 percent in $2004 .^{17}$ More encouragingly, responses to four questions used in 1996 and 2004 to measure respondent's political knowledge showed an increase in political cognition in every case.

There is a substantial body of literature establishing the important place that competitive political parties hold in both sustaining and consolidating democracy. ${ }^{18}$ Parties help voters structure their choices in meaningful ways, act to aggregate the public interest, recruit people into political participation and they can act as a source of accountability for those in power. Despite the obvious value of political parties to democracy, parties in Russia remain weakly institutionalised, explained in part, perhaps, by the weakness of Russia's civil society (Sakwa, 2001, p.106).

The data from our surveys suggest a disconnection between multi-party politics as an abstract concept and the way people actually feel about political parties. When asked if they felt the country needs a multi-party system, 58 percent of our respondents in 2004 said it did, up a few points from 1996 (54 percent) and 1990 when it was 52 percent. About a quarter of the respondents replied in the negative for each year. Yet, when asked which party they had confidence in, 30 percent replied "no party" with 40 percent supporting the current party of power, Unified Russia. All others received less than 10 percent. 
Before turning to the next section of this chapter, there are certain seeming anomalies in the preceding findings that merit attention. For one, our data indicate very low levels of political efficacy among our respondents, especially regarding the national government. Yet, levels of political trust are significantly higher. As we asked earlier: why would people place trust in a government they feel they cannot influence? Furthermore, following Stephen White's analysis cited earlier, how do we explain the finding there is broad support among Russians for electoral participation, when people don't feel voting matters much? Finally, why do respondents think political parties are such a good idea in the abstract, yet express indifference to them in practice? Because the questions used in our survey analysis don't readily address these questions, we turned to the results of our focus group interviews to try to understand what lay beneath the data.

The prompts we used in each two hour session were designed to determine what respondents understood democracy to mean (cognitive), whether they thought such a system desirable (affective), whether they thought Russia had a democracy (evaluative) and how they would explain any discrepancy between the ideal of democracy and what they thought Russia is. For all four of our focus groups, although in varying degrees, there was a fairly high level of cognition. People thought that democracy was about more than elections, but also about civil rights, equality of opportunity, a rule of law, and public accountability for those in office. Most also held the view that democracy was their preferred system of government, but they almost all also felt that Russia was not one. As one pensioner said, "Russia is about 30 percent a democracy; the rest is authoritarian."

Beyond these generalizations there are some important nuances, and some important generational differences. What emerges from our respondents, especially the older ones, is the view that democracy indeed requires political trust, but trust means that a good government 
(gosudarstvo) will take care of its citizens. At the same time, they seem to be saying that what such a government does not necessarily require is public input. It is a view of government that comes closer to the idea of trusteeship representation (Pitkin, p.127-28) than to an "instructed delegate" or mandate model. In a trusteeship model those elected exercise their best judgement about what to do on behalf their constituents independently of whether their constituents agree. The following exchange between a young woman aged 21-25 and a pensioner over fifty captures this view and the generational differences:

Moderator: "How do you imagine democracy?"

Younger girl: "For me, democracy is not only being equal before the law, but also about participating in making laws. It's also knowing your responsibilities and therefore knowing your rights."

Pensioner: "The girl talks about participating, rights and everything - that's wonderful, but imagine you work all day; do I really want to participate in politics? No!"

Girl: "But you do participate when you're voting, don't you?"

Pensioner: "Elections are a separate conversation. We don't have real elections..."

Girl: "But you have to trust your representatives."

Pensioner: "I don't have to trust anyone. When I can just live peacefully and let them make decisions at the top, that's when it's democracy."

Girl: "But that just develops a passive citizen who doesn't care what's going on."

Pensioner: "Democracy is just a term. In reality it's responsibility from the top (gosudarstvo), responsibility for me, and my children and for every person. From my side, it means trust in the officials, government bodies, and members of the soviet [sic!]. Democracy is not done through the Duma or what we have now. It's done through one person. It's not dictatorship though, it's democracy. My trust, I trust them - there is nothing for me to do in the government."

In the middle age group which consisted of eight women and two men between the age of 30 and 50, all possessing higher education, the same sense of government as trustee of the public good was expressed. One of the participants was a woman named Lena who explained that "we can't have democratic elections in Russia because people don't know who they are electing" and that people aren't really equal anyway. Her view of government comes close to paternalism.

\footnotetext{
Moderator: "So, Lena, to describe your position better, democracy as a form of equal rights doesn't exist?"

Lena:

“We can't have 50,000 people governing. We have to have a government for the people, a national government (narodnaya vlast'). Democracy is for everyone; it brings people closer to it. It's just like a parent deciding which child needs what and giving them that. That's how a democracy is, giving everyone what they need."
} 
Variations on this theme reappear throughout the interviews. For most, the answer to the question about how people can trust a government that they are powerless to influence is not a contradiction; a government that performs well is worthy of trust. As we will show below, the one political variable clearly linked to governmental performance is political trust. Only for the younger generation aged 21 to 25 who came of age after the Soviet Union collapsed, is there a sense that they can participate (internal efficacy) and should.

The focus group responses also hint at an answer to why support for elections and for a multiparty system might be fairly strong in our survey responses, yet respondents don't feel they can influence government and don't identify with political parties. The participants on our focus groups demonstrate a pretty good grasp of how democracies work ideally, but they also know that what they are living in falls far short of the ideal.

Therefore, one can endorse the need for elections and even a multi-party system as necessary in a democracy, and yet not see them as functioning very meaningfully in Russia under current conditions. From this point of view, support for a strong leader is not inconsistent with democracy; on the contrary, it is the strong leader who makes things work well that deserves public trust. As Resinger et al., (1994) caution, a response from Russians indicating support for a strong leader does not necessarily mean they want an authoritarian regime. As the authors write (p.215) about their Russian, Ukrainian and Lithuanian respondents "those desiring strong leadership were not expressing a wish for arbitrary or harmful leadership. Rather they were expressing a desire for 'good government' by means of finding the proper leaders and letting them govern". This brings us to the next set of findings from this research: the significance of economic performance to support for democratic values and institutions. 


\section{B. Does Economic Performance Explain Political Attitudes?}

We turn now to consider findings related to the second question that guided this research. To what extent do the measures of political support for democratic values and institutions used in this research reflect instrumental calculations of whether governmental performance has been effective or not? Following from the perspectives of rational choice theory, we hypothesised that those whose assessment of economic performance was negative would be less likely to hold attitudes favourable to democracy and also to be less supportive of political and economic reforms associated with building democracy in Russia.

To test this hypothesis, we first used responses to four questions measuring the respondent's assessment of economic performance. These measures are found in Table 4. The first two items are socio-tropic, and were asked both retrospectively and prospectively. The fourth item is egocentric and retrospective for three years, while the third item specifically asks what the government's economic role was over the previous year. Items three and four were both retrospective. Each item was correlated separately with the attitudes, values and beliefs related to diffuse support for democracy explored in the first section of this paper. An additive scale was created from the four items measuring perceptions of economic performance and was also correlated with the political variables.

Perhaps the clearest finding that emerges from this table is that the political variable most strongly correlated with economic assessments is political trust. This is true for all four of our independent variables. In almost all cases the correlation is greater than .20 and for the overall scale it is a robust .41 . For most of the political variables other than political trust, the correlation with economic assessments is weak or not significant (n.s.). No other correlation exceeds .16, a

more modest degree of association. ${ }^{19}$ In short, what the data seem to be telling us is that, political 
trust is indeed a function of how well the government performs just as rational choice theory would predict. Such a finding would seem to substantiate the position of those, like Jack Citron (1974), who argues that levels of political trust are not necessarily long lasting, but can change fairly quickly in response to more effective policies pursued by political leaders. For this reason, political trust should not be regarded as a value by which to measure political culture, but as an attitude that reflects short term calculations of personal advantage.

Table 4: Effect of Assessments of Economic Performance on Political Attitudes; Yaroslavl', Russia

$1996(\mathrm{~N}=962) ; 2004(\mathrm{~N}=1132)$. The correlation statistics for 1996 are reported above those for 2004 in each case.

\begin{tabular}{|c|c|c|c|c|c|c|}
\hline $\begin{array}{c}\text { Assessment of Economic } \\
\text { Change }\end{array}$ & $\begin{array}{l}\text { Low Political } \\
\text { Participation }\end{array}$ & $\begin{array}{c}\text { Low } \\
\text { Political } \\
\text { Efficacy }\end{array}$ & $\begin{array}{c}\text { Low } \\
\text { Political } \\
\text { Trust }\end{array}$ & $\begin{array}{c}\text { Low } \\
\text { Support for } \\
\text { Elections }\end{array}$ & $\begin{array}{c}\text { Low } \\
\text { Political } \\
\text { Interest }\end{array}$ & $\begin{array}{c}\text { Favors } \\
\text { Multi- } \\
\text { party } \\
\text { System }\end{array}$ \\
\hline $\begin{array}{l}\text { 1. Russia's economy has } \\
\text { worsened the past } 12\end{array}$ & n.s. & .11 & .31 & .09 & .11 & -.10 \\
\hline months & n.s. & n.s. & .19 & n.s. & n.s. & -.08 \\
\hline $\begin{array}{l}\text { 2. Russia's economy will } \\
\text { get worse in the next } 12\end{array}$ & n.s. & n.s. & .31 & n.s. & .09 & n.s. \\
\hline months & -.11 & n.s. & .23 & n.s. & n.s. & n.s. \\
\hline $\begin{array}{l}\text { 3. Federal policies have } \\
\text { made Russia's economy }\end{array}$ & .09 & .16 & .39 & n.s. & .09 & -.09 \\
\hline $\begin{array}{l}\text { worse over the past } 12 \\
\text { months }\end{array}$ & n.s. & .10 & .34 & .08 & n.s. & n.s. \\
\hline $\begin{array}{l}\text { 4. Respondent's } \\
\text { material well-being has }\end{array}$ & n.s. & .14 & .22 & .10 & .06 & -.14 \\
\hline $\begin{array}{l}\text { worsened in the past } \\
\text { three years }\end{array}$ & n.s. & n.s. & .15 & .08 & n.s. & n.s. \\
\hline \multirow{2}{*}{$\begin{array}{l}\text { 5. Scaled economic } \\
\text { assessment (items 1-4) }\end{array}$} & n.s. & .16 & .41 & n.s. & .11 & -.14 \\
\hline & n.s. & .12 & .41 & .09 & n.s. & -.10 \\
\hline
\end{tabular}

* Pearson's R correlations were used in all cases. Only correlations significant at the .05 level are reported. Correlations are between negative assessment of economic performance and the political and economic variables in the direction indicated for each. 
The other interesting finding that is also supported by Table 4 has to do with the differences between 1996 and 2004. With two minor exceptions, all the correlations for 2004 are lower than for $1996 .^{20}$ What that seems to tell us is that assessments of the economic situation were more important for how respondents felt politically in 1996. The explanation for this difference may lie in the fact that Russia was better off economically in 2004 than in 1996, a year of continuing economic dislocation for many and so economic issues were less salient for them. This interpretation would appear to be supported by other data from the survey that indicate that people were feeling better about the economy in 2004. Thus, in 1996, 44 percent rated the "provision of goods and products to population" to be an acute problem; by 2004, only 11 percent did while 58 percent responded that there was no problem. Another explanation may be that Putin is regarded so much more favorably as a leader than Yeltsin was.

The data from our survey also enable us to offer another look at the importance of economic assessments in explaining political attitudes. Table 5 and 6 summarize responses to a series of questions designed to find out how our respondents feel about the political and economic reforms often associated with building democracy in Russia. Table 5 presents responses to two sets of three questions related to political attitudes. One is intended to measure support for popular participation in politics, and the other, preferences for a strong leader. The first three questions were chosen to see if Russians trust public participation in decision making while the latter three go to the issue of whether Russians really prefer a more authoritarian form of leadership. 
Table 5: Attitudes Related to Political Reform in Yaroslavl; 1993 and 1996, 2004 (in percentages)

$\begin{array}{lccc}\text { POLITICAL ATTITUDES } & 1993 & 1996 & 2004 \\ (\mathrm{~N}=1019) & (\mathrm{N}=962) & (\mathrm{N}=1132)\end{array}$

A. Popular Participation

The complexity of today's problems allows only the simplest questions to be exposed to public scrutiny.

$\begin{array}{llll}\text { Agree } & 58 & 64 & 61 \\ \text { Disagree } & 42 & 36 & 39\end{array}$

A high level of public participation in making decisions often leads to unwanted conflicts.

$\begin{array}{llll}\text { Agree } & 76 & 66 & 62 \\ \text { Disagree } & 23 & 35 & 38\end{array}$

All citizens should have equal opportunity to influence government.

$\begin{array}{lccc}\text { Agree } & 80 & 82 & 85 \\ \text { Disagree } & 20 & 18 & 15 \\ & \mathrm{x}=1.97 & \mathrm{x}=2.08 & \mathrm{x}=2.06\end{array}$

Summary scale (mean score)*

$x=2.08 \quad x=2.06$

B. STRONG LEADER

Talented, strong-willed leaders always achieve success in any undertaking.

$\begin{array}{llll}\text { Agree } & 81 & 82 & 82 \\ \text { Disagree } & 19 & 18 & 18\end{array}$

A few strong leaders could do more for their countrv than all laws and discussion.

$\begin{array}{llll}\text { Agree } & 76 & 77 & 72 \\ \text { Disagree } & 25 & 28 & 28\end{array}$

There are situations when a leader should not divulge certain facts.

$\begin{array}{lccc}\text { Agree } & 88 & 83 & 80 \\ \text { Disagree } & 12 & 17 & 20 \\ & \mathrm{x}=2.07 & \mathrm{x}=2.20 & \mathrm{x}=2.12\end{array}$

Summary scale (mean score)*

$\mathrm{x}=2.20 \quad \mathrm{x}=2.12$

* The range for the summary scales is 1.00-3.00. The lower the mean score the greater the support for the variable. Scale reliability tests were performed and all scales exceeded the minimum mean inter-item correlation Correlation of .088. 
Table 6: Attitudes Related to Economic Reform: Yaroslavl 1993 and 1996, 2004 (in percentages)

$\begin{array}{lccc}\text { ECONOMIC ATTITUDES } & 1993 & 1996 & 2004 \\ (\mathrm{~N}=1019) & (\mathrm{N}=962) & (\mathrm{N}=1132)\end{array}$

A. Egalitarianism

An upper limit should exist on earnings so that no one accumulates more than anyone else.

$\begin{array}{llll}\text { Agree } & 51 & 53 & 48 \\ \text { Disagree } & 50 & 47 & 52\end{array}$

If others live in poverty, the government should react so that no one can become wealthy.

$\begin{array}{llll}\text { Agree } & 63 & 65 & 58 \\ \text { Disagree } & 37 & 35 & 42\end{array}$

Wealthy people should pay more than the poor

$\begin{array}{lccc}\text { Agree } & 93 & 94 & 85 \\ \text { Disagree } & 7 & 6 & 15\end{array}$

Summary scale (mean score) *

$\mathrm{x}=2.08 \quad \mathrm{x}=2.06 \quad \mathrm{x}=2.15$

B. FREE MARKET ECONOMY

A system based on profit brings out the worst in human nature

$\begin{array}{llll}\text { Agree } & 50 & 52 & 51 \\ \text { Disagree } & 50 & 48 & 49\end{array}$

A system of private enterprise is effective

$\begin{array}{llll}\text { Agree } & 68 & 69 & 71 \\ \text { Disagree } & 32 & 31 & 29\end{array}$

State regulation of business usually brings more harm than good

$\begin{array}{llll}\text { Agree } & 56 & 59 & 56 \\ \text { Disagree } & 45 & 41 & 45\end{array}$

The share of the private sector in business and industry today should be increased

$\begin{array}{llll}\text { Agree } & 70 & 61 & 59 \\ \text { Disagree } & 31 & 39 & 41\end{array}$

People accumulate wealth only at the expense of others

$\begin{array}{llll}\text { Agree } & 60 & 64 & 60 \\ \text { Disagree } & 40 & 36 & 40\end{array}$

Summary scale (mean score) * $\quad x=2.00 \quad x=2.15 \quad x=2.17$

* The range for summary scales is 1.00-3.00. The lower the mean score the greater the support for the variable. Scale reliability tests were performed and all scales exceeded the mean inter-item correlation of .088. 
On the question of popular participation, there seems to be some support for having the opportunity to do so, even though about 60 percent feel that some decisions are beyond their competence, a finding similar to the one reported earlier for internal efficacy. On the question of a strong leader, the data here confirm findings by other scholars (Reisinger, et al., 1994) that Russians prefer a 'strong hand', although as noted earlier they go on to argue ( p.189) such an attitude in not necessarily inconsistent with democratic leanings. About three quarters of our population seem to favor a rule of men over a rule of laws.

Table 6 looks at economic attitudes. The first three questions are aimed at measuring resentment of those who acquire more than their neighbor, a view that Russian folklore holds to be traditional. Yet, while it seems clear that our respondents feel that wealthy people should pay more than the poor, only about half think there should be a limit on how much one can accumulate. The second set of five questions, measure people's attitudes toward a free market economy. The response to the benefits of a market economy are mixed, but on the whole favorable; most think the private sector should be expanded and that state regulation of the economy "does more harm than good." What is quite remarkable about the data reported here is the relative consistency for all four measures in tables 5 and 6 over time. There are no dramatic swings of opinion between 1993, 1996 and $2004 .^{21}$

Each of the four sets of questions from table 5 and 6 was used to create four additive scales that became our dependent variables in Table 7 . Table 7 reports the findings when these variables were correlated with the independent variables measuring assessments of economic performance used in Table 4. There are two significant findings that emerge from this table. First, it seems clear that assessments of economic performance have little or nothing to do with the political preferences of our respondents, but they do appear to be related to how they feel 
about economic reforms. This finding would seem to be consistent with the conclusion offered by James Gibson (Gibson, 2001, p.123) that Russian views of economic reform may be driven by economic considerations, but not their political views. The second finding is that in almost all cases the strength of association is weaker in 2004 than in 1996 suggesting that assessments of economic performance are less important in 2004, perhaps reflecting an improved economy.

Such a finding would appear consistent with the one reported earlier from Table 3.

Table 7: Assessments of Economic Performance on Support for Political and Economic Reforms Yaroslavl', Russia

$1996(\mathrm{~N}=962) ; 2004(\mathrm{~N}=1132)$. The correlation statistics for 1996 are reported above those for 2004 in each case.

\begin{tabular}{|c|c|c|c|c|}
\hline Assessment of Economic Change & $\begin{array}{l}\text { Favor a } \\
\text { Strong } \\
\text { Leader }\end{array}$ & $\begin{array}{l}\text { Favor Popular } \\
\text { Participation }\end{array}$ & $\begin{array}{l}\text { Favor Economic } \\
\text { Equalization }\end{array}$ & $\begin{array}{c}\text { Favor a Market } \\
\text { Economy }\end{array}$ \\
\hline $\begin{array}{l}\text { 1. Russia's economy has worsened the } \\
\text { past } 12 \text { months }\end{array}$ & $\begin{array}{ll}\text { n.s. } \\
\text { n.s. }\end{array}$ & $\begin{array}{ll}\text { n.s. } \\
\text { n.s. }\end{array}$ & $\begin{array}{ll}.19 \\
\text { n.s. }\end{array}$ & $\begin{array}{l}-.15 \\
-.14\end{array}$ \\
\hline $\begin{array}{l}\text { 2. Russia's economy will get worse in } \\
\text { the next } 12 \text { months }\end{array}$ & $\begin{array}{l}\text { n.s. } \\
\text { n.s. }\end{array}$ & $\begin{array}{l}\text { n.s. } \\
\text { n.s. }\end{array}$ & $\begin{array}{l}.07 \\
.08\end{array}$ & $\begin{array}{l}-.13 \\
-.13\end{array}$ \\
\hline $\begin{array}{l}\text { 3. Federal policies have made } \\
\text { Russia's economy worse over the past } \\
12 \text { months }\end{array}$ & $\begin{array}{l}\text { n.s. } \\
\text { n.s. }\end{array}$ & $\begin{array}{l}\text { n.s. } \\
\text { n.s. }\end{array}$ & $\begin{array}{l}.08 \\
.08\end{array}$ & $\begin{array}{l}-.15 \\
-.14\end{array}$ \\
\hline $\begin{array}{l}\text { 4. Respondent's material well-being } \\
\text { has worsened in the past three years }\end{array}$ & $\begin{array}{l}\text { n.s. } \\
\text { n.s. }\end{array}$ & $\begin{array}{l}\text { n.s. } \\
-.13\end{array}$ & $\begin{array}{l}.20 \\
.06\end{array}$ & $\begin{array}{l}-.17 \\
\text { n.s. }\end{array}$ \\
\hline $\begin{array}{l}\text { 5. Scaled economic assessment } \\
\text { (items 1-4) }\end{array}$ & $\begin{array}{l}\text { n.s. } \\
\text { n.s. }\end{array}$ & $\begin{array}{l}\text { n.s. } \\
\text { n.s. }\end{array}$ & $\begin{array}{l}.18 \\
.16\end{array}$ & $\begin{array}{l}-.25 \\
-.22\end{array}$ \\
\hline
\end{tabular}

* Pearson's R correlations were used in all cases. Only correlations significant at the .05 level are reported. Correlations are between negative assessment of economic performance and the political and economic variables in the direction indicated for each.

\section{Conclusions}

The major purpose of this chapter was to determine how much change had taken place in support for political attitudes, values and beliefs associated with democracy since serious survey research into the democratic experiment in Russia began in 1990. More particularly, we wanted 
to see if there had been any significant change from the Yeltsin years after his successor's first term in office. As noted earlier, the findings offered here are based on replicable survey research conducted among the predominantly ethnically Russian population of Yaroslavl' in 1990, 1993, 1996 and 2004. Focus group interviews conducted in 2004 were also used to help understand some of the anomalous findings that emerged from the survey data.

Our general finding is that there has been relatively little change in political attitudes, values and beliefs of our respondents since 1993. Because earlier analyses of these data (Hahn, 2001) showed an erosion of support for these variables, especially from 1990 to 1993, our expectation was that further erosion would be likely. Yet the comparison of data from 1996 to 2004 does not suggest that any such erosion. On the contrary, there was, if anything, an upswing of support for most variables, including, political trust, civic duty, political interest and cognition, and support for a multi-party system. Levels of political efficacy remained low, but improved after 1993 for some measures of subjective competence. Only political interest showed a modest decline in this period. Moreover, the attitudes related to political and economic reform examined in Tables 5 and 6 similarly show little change from 1996 to $2004 .^{22}$ Among the measures used, it is important to reiterate that political trust as a variable seems to be an attitude responsive to government policies of the day and subject to short term fluctuation, not an enduring value which can be associated with support for democracy as the other variables seem to be.

The other major finding here is that short-term assessments of government performance explain some, but by no means all, of the variance in our political variables, offering only partial support for our second hypothesis. Of the political attitudes, values, and beliefs discussed in the first section of this chapter, only political trust clearly seems to be related to perceptions of how 
well the government is performing economically. The other variables were at most weakly related to such perceptions. Thus, this variable at least would appear to be a specific and contingent source of support. Finally, one finding regarding the importance of perceived economic performance that clearly emerges from our analysis is that such assessments appear to have a definite impact on how people feel about economic changes, but not about political ones. This would appear to confirm the findings of James Gibson (2001) cited earlier.

Finally what are the implications of our findings regarding prospects for democracy in Russia? At least for our respondents, there seems to be at some level a continuing normative commitment to democracy, even though most feel that contemporary Russia is not very democratic. Putin's systematic undermining since 2000 of institutional sources of accountability such as the media, regional executives and the legislature, among others, does not appear to have been accompanied by any steep erosion of this normative commitment. Nevertheless, Putin enjoys widespread popular support.

Why? The most straightforward explanation for this apparent contradiction is that most people feel better off than they did under Yeltsin; that is, for many, government has become more effective. Yet, it would clearly be a mistake to conflate support for governmental performance with support for democracy, although they are also certainly not necessarily contradictory; those living is democratic societies would surely value both. It would also certainly be wrong to equate support for Putin with support for democracy. However, it would also be a mistake to conclude that Putin necessarily signifies a reversion to authoritarianism 
among Russians. If it did we would have found evidence of a change in that direction among our respondents and we did not. In short, Putin may well continue to implement undemocratic policies, but it seems from the findings presented here that he should not assume that there is a strongly authoritarian Russian political culture that will indefinitely support them. 


\section{BIBLIOGRAPHY}

Alexander, James (2000), Political Culture in Post Soviet Russia: Formlessness and Recreation in a Traumatic Transition, New York, St. Martin's Press.

Almond, Gabriel A. (1990), 'Communism and Political culture Theory' in Almond, G., ed. A Discipline Divided: Schools and Sects in Political Science, California, Sage Publications.

Almond, Gabriel A. and Sidney Verba (1963) The Civic Culture, Princeton, NJ, University Press.

Bahry, Donna (1999), 'Comrades into Citizens? Russian Political Culture and Public Support for the Transition,' Slavic Review 58:4:841-852.

Balzer, Harley (2003), 'Managed Pluralism: Vladimir Putin's Emerging Regime,' Post- Soviet Affairs, 19:3:189-227.

Brown, Archie (1984), ed. Political Culture and Communist Studies, London, MacMillan.

Brown, Archie (1989), 'Ideology and Political Culture' in Seweryn Bialer, ed. Politics, Society and Nationality Inside Gorbachev's Russia, Boulder, Westview Press.

Brown, Archie (1996), 'Political Culture' in Adam Kuper and Jessica Kuper, eds., The Social Science Encyclopedia $2^{\text {nd }}$ edition, London and New York, Routledge.

Brown, Archie (2001), 'Evaluating Russia's Democratization,' in A. Brown ed., Contemporary Russian Politics: A Reader, Oxford, University Press.

Brown, Archie (2003), 'Political Culture and Democratization: The Russian Case in Comparative Perspective' chapter 2 in Detlef Pollack, Jürg Jacobs, Olaf Müller and Gert Pickel, eds., Political Culture in Post-Communist Europe: Attitudes in New Democracies, Ashgate, Aldershot, pp.17-27.

Brown, Archie (2005), 'Cultural Change and Continuity in the Transition from Communism: The Russian Case' in Lawrence E. Harrison and Peter Berger, eds., Developing Cultures: Case Studies, London and New York, Routledge.

Brown, Archie and Jack Gray (1977), eds. Political Culture and Political Change in Communist Societies, London, MacMillan Press.

Campbell, Angus, Gerald Gurin, and Warren E. Miller (1954), The Voter Decides, New York, Harper and Row.

Campbell, Angus, Philip E. Converse, Warren F. Miller and Donald Stokes (1960), The American Voter, New York, John Wiley and Sons. 
Campbell, Bruce A. (1979), The American Electorate: Attitudes and Action, NY, Holt, Rinehart and Winston.

Citron, Jack (1974) 'Comment: The Political Relevance of Trust in Government' American Political Science Review 68: 973-988.

Colton, Timothy J., and Michael McFaul (2002), ‘Are Russians Undemocratic?' Post-Soviet Affairs, 18:2:91-121.

Daniels Robert V. (2000), 'Russia’s Democratic Dictatorship,' Dissent, 47: 3: 9-14.

Easton, David (1965), A Systems Analysis of Political Life, New York, John Wiley and Sons.

Gibson, James L. Raymond M. Duch, and Kent L. Tedin (1992) 'Democratic Values and the Transformation of the Soviet Union,' Journal of Politics, 54: 329-371.

Gibson, James L. (1996), 'A Mile Wide But an Inch Deep (?): The Structure of Democratic Commitment in the Former USSR,' American Journal of Political Science 40: 396-420.

Gibson, James L. (2001), 'The Russian Dance with Democracy,' Post-Soviet Affairs, 17:2:101128.

Golosov, Grigorii (2004) 'Political Parties in the Regions of Russia: Democracy Unclaimed,' Boulder, Colorado, Lynne Rienner.

Hahn, Jeffrey W. (1991), 'Continuity and Change in Russian Political Culture,' British Journal of Political Science 21:393-421.

Hahn, Jeffrey W. (2001), 'Political Culture in Yaroslavl' Over Time: How “Civic”?', in Jeffrey W. Hahn, ed. Regional Russia in Transition, Baltimore, Johns Hopkins Press.

Heatherington, Marc (1998) 'The Political Relevance of Political Trust,' American Political Science Review 92: 4: 791-808.

Herspring, Dale R. (2005), 'Conclusions' in Dale R. Herspring ed., Putin's Russia: Past Imperfect, Future Uncertain, Lanham, MD, Rowman and Littlefield.

Huskey, Eugene (2001), 'Overcoming the Yeltsin Legacy: Vladimir Putin and Russian Political Reform' in Archie Brown ed., Contemporary Russian Politics: A Reader, Oxford, University Press.

Karaman, Tatyana (2004), 'Political Efficacy and Its Antecedents in Contemporary Russia,' The Journal of Communist Studies and Transition Politics, 20:2:30-49.

Kruger Richard A. (1994), Focus Groups: A Practical Guide for Applied Research, $2^{\text {nd }}$. Ed. (CA: Sage Publications). 
Lukin, Alexander (2000), The Political Culture of the Russian 'Democrats' Oxford, University Press.

Miller, Warren E. and Santa Traugott (1989), American National Election Studies Data Sourcebook, 1952-1986, Cambridge, Massachusetts, Harvard University Press.

O’Donnell, Guillermo (1994), 'Delegative Democracy,' Journal of Democracy, 5 (1), 55-69.

Petro, Nicolai N. (1995), The Rebirth of Russian Democracy: An Interpretation of Political Culture, Cambridge, Harvard University Press.

Pitkin, Hannah Fenichal (1967) The Concept of Representation, Berkeley, California, University Press.

Reisinger, William M., Arthur H. Miller, Vicki L. Hesli, and Kristen Maher (1994) 'Political Values in Russia, Ukraine and Lithuania: Sources and Implications for Democracy' British Journal of Political Science 25: 183-223.

Remington, Thomas F. (2000), 'The Evolution of Executive-Legislative Relations in Russia since 1993,' Slavic Review, 59:3:499-520.

Ross, Cameron (2002), Federalism and Democratization in Russia Manchester, UK, University Press.

Sakwa, Richard (2001), 'Parties and Organized Interests,' in Stephen White, et al., eds. Developments in Russian Politics, Durham, NC, Duke University Press.

Shevtsova, Lilia (1999), Yeltsin's Russia, Washington, D.C., Carnegie Endowment for Peace.

Welch, Stephen (1993), The Concept of Political Culture, London, MacMillan Press.

White, Stephen (1979), Political Culture and Soviet Politics, New York, St. Martin's Press.

White, Stephen (1984), 'Soviet Political Culture Reassessed,' in Archie Brown, ed. Political Culture and Communist Studies, London, MacMillan.

White, Stephen (2002), 'Ten years On, What Do Russians Think?' Communist Studies and Transition Politics, 18:1: 35-50.

Whitefield, Stephen (2005), 'Culture, Experience and State Identity' (forthcoming).

Whitefield, Stephen and Geoffrey Evans (1994), 'The Russian Election of 1993: Public Opinion and the Transition Experience,' Post-Soviet Affairs, 10: 1: 36-60. 
Whitefield, Stephen and Geoffrey Evans (1999) 'Political Culture vs. Rational Choice: Explaining Responses to Transitions in the Czech Republic and Slovakia,' British Journal of Political Science, 29: 129-155.

Wyman, Matthew (1997) Public Opinion in Post- Communist Russia, New York: St. Martin's Press. 


\section{ENDNOTES}

1 The author wishes to acknowledge with gratitude funds provided in 2004 by the National Council of Eurasian and East European Research (NCEEER), under authority of a Title VIII grant from the U.S. Department of State, in 2004 which enabled him to conduct the research on which this chapter is based. Neither NCEEER nor the U.S. Government is responsible for the views expressed in this text.

There are many people who contributed to the research reported here, too many to thank individually; they know who they are. But, two deserve special mention. I am indebted to Nurit Friedman who performed the data analysis with exceptional speed and competence. He would also like to thank his graduate student at Villanova, Lilit Poghossian, for her work in making transcripts of the focus groups sessions and for her analysis of them.

${ }^{2}$ Not all scholars conclude the Yeltsin's Russia was entirely without institutional constraints. See Remington (2000) on parliamentary constraints and Golosov's argument (2004) that at least until 2000, Russia's regions also acted to limit central authority.

${ }^{3}$ See the discussion by Colton and McFaul (Colton and McFaul, 2002) of the "new narrative" they say is emerging about how Russians preference for Putin signals a return their authoritarian roots. Colton and McFaul go on to dispute this view.

${ }^{4}$ For a further review of this literature see Hahn, 1991, p.397-399. An alternative version of the cultural continuity thesis which argues that there were important democratic elements in pre-revolutionary Russian political culture that may contribute to the process of democratisation in Russia can be found in Petro (1995).

${ }^{5}$ While Brown (2003) is probably right in saying (p.18) that "a majority of scholars who employ the concept in a serious way" use the subjectivist approach, there are those who disagree. Among them are those who favour a more "interpretivist" approach that includes behaviour in the definition. It is associated with the anthropological methods used by followers of Clifford Geertz and Max Weber. Stephen White's approach to Soviet political culture (White, 1979) is closer to this school of thought. Stephen Welch (Welch 1993) rejects both the subjective approach, which he labels "comparativist", and the interpretivist school, in favour of a phenomenological one. In his view (p.108; 162), political culture, indeed all culture, emerges through human experience with the world. As humans interact with the world around them they attribute meaning to it and through a process of "habitualization" eventually "man constructs his own nature". Welch's approach has been adopted by Alexander Lukin (p.4) in his attempt to understand the political culture of the leadership of the democratic movement during perestroika.

${ }^{6}$ This approach is similar to that of Donna Bahry (Bahry, 1999, p.843). As Brown has pointed out (Brown, 2003, p. 18) within any state a variety of sub-cultures likely exist, but that this doesn't preclude speaking of widely shared assumptions, such as the right to influence political outcomes in democratic countries, within a state as a whole. However, Brown cautions that when the notion of political culture is applied to whole countries, it should not be taken to imply that there are no values differences within the society.

${ }^{7}$ One of the main findings in this chapter is that the political trust variable appears to be explained by short term economic assessments related to government performance. As such it must be regarded more as an attitude than an enduring value related to democracy. The other variables however, do appear to be values related to democracy.

${ }^{8}$ Brown made this criticism without having available the subsequent replicate research carried out in 1993 and 1996. In a later work (Brown 2005) Archie Brown generously revised his assessment of what can be learned from research in one area of Russia if it is replicated. Referring to my book (2001) he writes "What Hahn finds in this one Russian region appears to hold good for much of Russia including its central government, namely that "while progress in introducing the forms of democracy has been undeniable, changing the norms and practices that go with it has been less successful'.

${ }^{9}$ Further details of how the sample was taken and how the survey was conducted will be readily made available by the author. 
${ }^{10}$ The distinction between specific and diffuse source of political support was first made by David Easton. Specific support is more closely tied to political outputs and regime performance while diffuse supports are based on longer term sources of loyalty and a willingness to accept the regime as legitimate.

${ }^{11}$ The dependent variables chosen here come from studies of American voting behavior which have been conducted since the early 1950's. They measure diffuse support for the American political system over time (Miller and Traugott, chapter 4). The questions used to measure each variable in the current research are Russian language versions of those used in the American surveys. There are several reasons for this approach. First, it enabled us to compare how similar or different Russian responses would be to those found in a country regarded as a modern democracy, a major concern of the original study (Hahn, 1991). While additional questions were added for subsequent surveys, the original questions are those that provided the basis for replication. Finally, these variables arguably measure enduring political values associated with living in a democratic society, although it is a major conclusion of this study that political trust is an attitude subject to short term situational change rather than a value which the other variables arguably are. For each variable there is a brief discussion in the body of the text as to how these variables have been linked to support for democracy.

${ }^{12}$ Data on American responses from 1952 to 1987 to similar questions measuring political efficacy and the other variables measuring diffuse system support used in this study can be found in Miller and Traugott, 1989. More recent data up to the present can be found on the web site maintained by Centre for Political Studies at the University of Michigan. See: http://www.isr.umich.edu/cps/

${ }^{13}$ Questions on national efficacy contained qualifier "of the country" (pravitel'stvo strani) while those referring to local government asked about the city administration (gorodskaia administratsiia) or the municipality (munitsipalitet).

${ }^{14}$ The question was: "Imagine that the city municipal council has made a decision which you consider incorrect or capable of causing damage. What do you think you could do in such a situation?"

15 Confidence in the Russian State Duma rose from 27 percent expressing some or complete confidence in 1996 to 38 percent in 2004. In both years 51 percent also expressed little or no confidence.

${ }^{16}$ The question comes from the University of Michigan ICPSR National Election Studies survey conducted annually. It reads: "Some people seem to follow what's going on in government and politics most of the time, whether there's an election or not. Others aren't that interested. Would you say you follow what's going on in government most of the time, some of the time, now and then, or hardly at all?"

${ }^{17}$ While these figures represent a decline of political interest, they are not far from those found in other democratic countries. The comparable figure for the USA in 1994 for example was 69 percent.

${ }^{18}$ A useful summary of much of this literature can be found in Ross, p. 96-97.

${ }^{19}$ Only two other variables seem even modestly responsive to economic assessments, political efficacy and unexpectedly, support for a multi-party system. But neither variable correlates with the prospective measure of performance (item 2) and neither exceeds a correlation of .16 for any association with most associations being non significant (n.s.)

${ }^{20}$ The two exceptions are item 2 and political participation, and item 3 and support for elections.

${ }^{21}$ The questions in table 5 and 6 were not asked in the 1990 survey, so comparisons from that date are not possible.

${ }^{22}$ Within this general finding there are two positive indicators worth emphasizing. One is that both efficacy and trust measures are greater at the local level of government and, at least for trust, has increased steadily. The other is that measures of internal efficacy are higher than those for external efficacy, suggesting that people may be more ready to participate politically, especially locally. 